\title{
The Link Between Religion and Helping Others: The Role of Values, Ideas, and Language
}

\author{
Christopher J. Einolf* \\ DePaul University
}

This study used life narrative interview data from the Midlife in the United States (MIDUS) study to examine how religious values, ideas, and language motivate prosocial behaviors. Open coding of 88 in-depth interviews revealed six themes: defining morality in religious terms, considering religion an important aspect of one's identity, feeling that one's life involves carrying out God's mission, making an increased commitment to religion over time, drawing an explicit connection between religion and helping others, and, for Christian respondents, finding inspiration for helping in Jesus's teaching, example, and sacrifice. Using ratings from independent coders, statistically significant relationships were found between most of the themes and prosocial behaviors, particularly for respondents who engaged in multiple helping behaviors. In addition to documenting the relationship between religious ideas and values and helping behaviors, the study demonstrates how language mediates the relationship between the social and personal aspects of religion.

Key words: beliefs; civil society/public sphere; nonprofit sector; qualitative methods; values; prosocial behavior.

The importance of helping others is a common theme in many religious traditions, and many scientific studies have found a link between religiosity and helping. However, the exact nature of this link is disputed. Sociologists who study this issue tend to explain the connection between religion and helping by reference to the social networks that come with religious participation (Becker and Dhingra 2001; Cnaan et al. 1993; Musick and Wilson 2008; Musick et al. 2000; Park and Smith 2000; Wilson 2000). Psychologists tend to focus on subjective aspects of religiosity, such as values, motivations, attitudes, and beliefs (Clary and Snyder 1991; Clary et al. 1998; Cnaan and

*Direct correspondence to Christopher J. Einolf, E-mail: ceinolf@depaul.edu.

(C) The Author 2011. Published by Oxford University Press on behalf of the Association for the Sociology of Religion. All rights reserved. For permissions, please e-mail: journals.permissions@oup.com. 


\section{SOCIOLOGY OF RELIGION}

Goldberg-Glen 1991; Omoto et al. 2000). Most psychological studies of the relationship between subjective religiosity and helping use quantitative measures of subjective religiosity, and most find only moderate correlations between religiosity and helping (Saroglou 2006).

This paper focuses on subjective religiosity, and argues that religious values, ideas, and language are not merely psychological phenomena but are also social facts. People learn religious ideas and values from others, and internalize them into their own sense of identity. They draw upon these ideas to engage in social behaviors, and use language to construct accounts that explain why they help others, and what helping others means to them. Taking ideas and language seriously allows for a broader and more accurate understanding of the connection between religion and helping, and allows researchers to connect the internal world of the mind with the external world of social discourse.

This paper analyzes data from 88 in-depth life narrative interviews undertaken as part of the 1995 Midlife in the United States (MIDUS) study. The first phase of this research project used open coding to identify six themes in how respondents talked about religion. These themes were defining morality in religious terms, considering religion an important aspect of one's identity, feeling that one's life involves carrying out God's mission, making an increased commitment to religion through the adult life course, drawing an explicit connection between religion and helping others, and, among Christians, of finding inspiration for helping either in Jesus's example and teaching or in Jesus's sacrifice for human sin.

During the second phase of this project, independent coders followed a quantitative coding scheme to determine whether each of the six themes correlated with helping behaviors. Four themes correlated significantly with helping others: considering religion an important aspect of one's identity, making an increased commitment to religion through the adult life course, drawing a connection between religion and helping, and finding inspiration in Jesus's example and sacrifice. The third section presents detailed excerpts from the narratives of three of the most highly prosocial people in the sample. These narratives show how religious themes are particularly prominent in the life narratives of highly prosocial people, and how liberal Christians and born-again Christians differ in how they find inspiration for helping in Jesus. They also show how people use language to learn and internalize religious values, put them into action through helping others, and then justify their helping behaviors through narrative accounts.

\section{BACKGROUND}

A major difficulty in establishing the nature of the link between religiosity and prosocial behavior is the fact that scholars disagree on how to define and 
measure the two concepts. This section first addresses the definition and measurement of religiosity, and the definition and measurement of prosocial behavior, before reviewing the literature on the relationship between the two.

There is a long history of attempts to conceptualize and measure religiosity, and social scientists have used a variety of measures. A commonly used distinction is that between religiosity that is external, or expressed through action, and religiosity that is internal, or within the minds of individuals (Idler et al. 2003). Within the domain of internal religiosity, researchers have identified feelings, values, beliefs, motivations, coping practices, and meaning as measurable characteristics. One such variable is "divine control," or "the extent to which one perceives that God controls the direction and outcomes of his or her life" (Schieman and Bierman 2007:363).

This paper focuses on internal religiosity, with the goal of discovering and testing new connections between internal religiosity and prosocial behavior. While internal religiosity can seem personal and private, it is actually profoundly social, as people develop their religious thinking through social institutions and express them through a common language. As Wuthnow (1991:45) stated, helping actions are not merely "a set of behaviors," but also "the languages we use to make sense of such behaviors." The study of language "inevitably moves us from the level of the individual to the level of society," as language embodies the "cultural frameworks" that we use to make sense of our behaviors. This study examines how people use the language of American culture and Christian belief to connect their religious thoughts and feelings to their helping behaviors.

As the term "altruism" is a contentious one within psychology, due to disputes over motivation and nonmaterial rewards for helping (Batson 1991; Piliavin and Charng 1990), this study uses the terms "prosocial behavior" and "helping," and focuses on volunteering, charitable giving, and helping others through paid employment. Many studies have found a connection between religiosity and prosocial behavior. These include psychological studies of volunteer motivation (Clary and Snyder 1991; Clary et al. 1998; Cnaan and Goldberg-Glen 1991; Omoto et al. 2000), surveys of college students (MacLean et al. 2004; Saroglou et al. 2005), and survey studies of charitable donors (Hoge 1995; Hoge et al. 1996, 1998; Toppe et al. 2001).

Sociological studies tend to argue that social networks explain most of the variation in religious giving and volunteering, and that subjective religiosity matters little (Wilson 2000; Musick and Wilson 2008). Quantitative studies of religion and helping tend to support this argument, as measures of congregational membership and attendance at services correlate with helping more than measures of subjective religiosity (Becker and Dhingra 2001; Cnaan et al. 1993; Musick et al. 2000; Park and Smith 2000). Some studies, however, have found a relationship between subjective religiosity and helping others that is robust to the inclusion of measures of religious behaviors (Regnerus et al. 1998; Wuthnow 2004). 


\section{SOCIOLOGY OF RELIGION}

Most of these quantitative studies use simple single-item measures of subjective religiosity, such as how important the respondents' religion is to them (Becker and Dhingra 2001; Musick et al. 2000; Park and Smith 2000; Regnerus et al. 1998). Qualitative methods would be more effective in exploring the exact nature of the link between subjective religiosity and helping, but qualitative studies are surprisingly rare. Some interview studies of highly prosocial people include brief mentions of religious motives (Lee et al. 2005; Mastain 2007; Yeung 2004), but only a few contain a detailed analysis of how religious values, feelings, and identity motivate helping others. Four such studies are detailed below.

Using both survey and interview data, Wuthnow (1991) found that regular church attendees who reported that they often felt the influence of divine love were more likely to do volunteer work. Churchgoers who could recount the story of the Good Samaritan, and churchgoers who stated that their religious beliefs made them more kind and caring, were also more likely to be involved in charitable activities. However, for those respondents who rarely or never attended church, subjective religiosity did not predict volunteering. Wuthnow concluded that subjective religiosity is a potentially important motivation for helping, but translates into action only among individuals who belong to a religious community.

Wuthnow also distinguished between liberal and conservative Christian approaches to helping. While liberals and conservatives both agreed that helping others is important, and engaged in similar amounts and types of helping behaviors, they had different understandings of the connection between religion and helping. Conservatives were more likely to cite religion as an important motive for helping, and were more likely "to be driven by the desire to give, even sacrifice themselves" (Wuthnow 1991:133). Conservatives were more likely to feel they had debts to repay to God or society, and more likely to reject materialism. Liberals tended to cite values derived from other sources than religion to explain why they helped others.

Several qualitative studies have found that religion is an important feature in the lives of many highly prosocial people. Two studies of highly prosocial "moral exemplars" (Colby and Damon 1992; Perry et al. 2008) found that the majority cited religion or spirituality as a reason for helping others. Furthermore, these exemplars did not compartmentalize their lives into religion, personal life, and helping work, but considered their spiritual or religious beliefs, helping behaviors, and personal identity to be "highly integrated" into a single whole (Perry et al. 2008: 452). A study of non-Jews who rescued Jews during the Holocaust found that about 15 percent of rescuers cited religious motives. While rescuers were not more religious than nonrescuers, they differed "in their interpretation of religious teaching and religious commitment, which emphasized the common humanity of all people and therefore supported efforts to help Jews" (Oliner and Oliner 1988:156). 
In summary, the literature on the association between subjective religiosity and helping others is dominated by survey research, which seeks statistical correlations between quantitative measures of subjective religiosity and quantitative measures of volunteering and charitable giving. With the exception of Wuthnow, sociologists of religion have given little attention to the role of language in the relationship between religion and helping, and have thereby oversimplified the analysis of religion into a quantification of social networks. Such an approach neglects the role of ideas, values, and identity. A focus on language allows us to understand how people acquire ideas about helping others from religious texts, sermons, and conversations, internalize these ideas and make them their own, express them through helping behaviors, and explain their behaviors to others through narrative accounts. This presents a much richer and complex understanding of religious groups, ideas, and behavior than one that focuses exclusively on quantitative measures of subjective religiosity and religious attendance.

\section{METHOD}

This article analyzes interview data, first by using open-ended coding to generate hypotheses, and then by using quantitative coding to test them. The findings section of this article is divided into three sections. First, it reports the results of open coding for hypothesis generation. Second, it reports the results of tests of those hypotheses using numeric coding by independent coders, and data from a mail survey that were collected before the interviews. The advantage of this two-stage approach is that it makes possible both the generation of new hypotheses and the testing of those hypotheses, using different coders but the same data. The third section presents excerpts from full interviews to demonstrate the particular importance of religion in the lives of highly prosocial people, and to show how Jesus plays a different role in motivating the prosocial behaviors of born-again and liberal Christians.

This article uses interview data from the 1995 wave of the MacArthur Foundation's MIDUS study. The MIDUS study surveyed a nationally representative random-digit dialing sample of noninstitutionalized, English-speaking adults, born between 1920 and 1970, and had an estimated overall response rate of 60.8 percent. From the 3,032 members of the main wave of the 1995 MIDUS survey, researchers randomly selected 94 individuals living near five U.S. cities for life history interviews. Full information about the overall sample and response rate is contained in the MIDUS codebook, available from the MIDUS web site at midmac.med.harvard.edu/research.html. While the MIDUS interview sample is not perfectly representative of the U.S. population, it is much more nearly representative than most qualitative interview samples. As there was no attempt to oversample non-Christians, the sample contained 
only nine non-Christian respondents, of whom one was an atheist, seven were agnostics, and one was Jewish.

The main focus of the interviews was respondents' prosocial action in the domains of family, politics, religion, paid employment, volunteer work, and charitable giving. Interviewers asked respondents to define how they interpreted morality, to describe their religious beliefs, to describe their participation in religious activities, how important religion was to their sense of self, and how their religious beliefs had changed over time. Eighty-eight of these interviews are used in this study. Three are unusable because of gaps in the tape, inaudible responses, or incomplete transcription, and another three are unusable because the interviewers failed to ask the questions about religion. The interviews were two to three hours in length, and the transcripts comprise a total of more than 2,500 single-spaced pages of text, making them an extensive and potentially rich source of data. To date, only one study has been published using these transcripts (Colby et al. 2001), and this study analyzed only the portions of the interviews relating to social responsibility through paid employment.

For the initial phase in the research, I used an open coding strategy, searching for patterns and themes that emerged from the interview data. Six themes seemed particularly prominent among respondents who reported a significant commitment to helping others: considering religion a central part of their sense of identity, having a religious definition of morality, equating religion with helping others, feeling that God has a mission for their lives, being inspired by Jesus's sacrifice or example, and reporting a major change or gradual increase of religious faith with time.

I tested the relationship between these six themes and helping others by having three research assistants code the interviews. I provided the coders with definitions of the themes, had them code 10 cases, and then met with them to compare how they assigned codes. After a discussion of different coding decisions and clarification of what the categories meant, the coders rated the rest of the interviews independently. I determined the strength of coder agreement through a measure of the percentage of cases upon which all three coders agreed, and through Cohen's $\kappa$. Where the coders did not agree, I applied the code assigned by two out of the three coders. Table 1 shows the percent of cases for which all three coders agreed, and the percentage of cases where the theme was present. Having coded the themes, I then examined the relationship between the religiosity themes and prosocial behaviors using cross-tabular tables. I tested for statistical significance with Pearson's $\chi^{2}$, and used Kendall's $\tau$-b, a measure of correlation between ordinal variables, to measure the strength of the association.

For volunteering and charitable giving, I used data from the survey portion of the MIDUS study, which asked respondents to report how many hours they spent in the last month volunteering, and how much money they donated to secular and religious charities. I recoded these variables to a dichotomous measure of who did and who did not participate in each activity. I also created a variable measuring combined participation in volunteering, religious giving, 
TABLE 1 Descriptive Statistics and Interrater Reliability Measures

\begin{tabular}{|c|c|c|c|c|c|c|c|}
\hline \multirow[t]{3}{*}{ Variable } & \multirow{2}{*}{\multicolumn{3}{|c|}{ Descriptive statistics }} & \multicolumn{4}{|c|}{ Reliability measures } \\
\hline & & & & \multirow[b]{2}{*}{$\begin{array}{l}\text { Percent full } \\
\text { coder agreement }\end{array}$} & \multicolumn{3}{|c|}{ Cohen's $\kappa$} \\
\hline & $\begin{array}{l}\text { Number } \\
\text { yes }^{\text {a }}\end{array}$ & $\begin{array}{l}\text { Number } \\
\text { valid cases }\end{array}$ & $\begin{array}{l}\text { Percent } \\
\text { yes }^{\mathrm{a}}\end{array}$ & & $\begin{array}{l}\text { Coders } \\
1 \text { and } 2 \\
\end{array}$ & $\begin{array}{l}\text { Coders } \\
2 \text { and } 3 \\
\end{array}$ & $\begin{array}{l}\text { Coders } \\
1 \text { and } 3 \\
\end{array}$ \\
\hline \multicolumn{8}{|l|}{ Religiosity measures } \\
\hline Religious identity & 24 & 64 & 37.5 & 68.8 & 0.253 & 0.462 & 0.259 \\
\hline Religious morality & 18 & 86 & 20.1 & 81.8 & 0.698 & 0.622 & 0.777 \\
\hline Religion $=$ helping & 24 & 88 & 27.3 & 67.0 & 0.417 & 0.410 & 0.406 \\
\hline God's mission & 18 & 87 & 20.7 & 64.8 & 0.495 & 0.260 & 0.450 \\
\hline Jesus's teaching and example ${ }^{b}$ & 7 & 79 & 8.9 & 70.5 & 0.506 & 0.306 & 0.280 \\
\hline Christ's sacrifice ${ }^{\mathrm{b}}$ & 3 & 79 & 3.8 & 80.7 & 0.325 & 0.383 & 0.651 \\
\hline $\begin{array}{l}\text { Increase over time } \\
\text { (four categories) }\end{array}$ & 20 & 83 & 24.1 & 39.8 & 0.378 & 0.378 & 0.546 \\
\hline $\begin{array}{l}\text { Increase or major change } \\
\text { over time (two categories) }\end{array}$ & 20 & 81 & 24.7 & 65.4 & 0.493 & 0.414 & 0.605 \\
\hline \multicolumn{8}{|l|}{ Prosocial behaviors } \\
\hline Volunteering ${ }^{\mathrm{c}}$ & 34 & 88 & 38.6 & $\mathrm{n} / \mathrm{a}$ & $\mathrm{n} / \mathrm{a}$ & $\mathrm{n} / \mathrm{a}$ & $\mathrm{n} / \mathrm{a}$ \\
\hline Religious giving ${ }^{c}$ & 37 & 88 & 42.0 & $\mathrm{n} / \mathrm{a}$ & $\mathrm{n} / \mathrm{a}$ & $\mathrm{n} / \mathrm{a}$ & $\mathrm{n} / \mathrm{a}$ \\
\hline Secular giving ${ }^{\mathrm{c}}$ & 50 & 88 & 56.8 & $\mathrm{n} / \mathrm{a}$ & $\mathrm{n} / \mathrm{a}$ & $\mathrm{n} / \mathrm{a}$ & $\mathrm{n} / \mathrm{a}$ \\
\hline All three combined ${ }^{c}$ & 16 & 88 & 18.2 & $\mathrm{n} / \mathrm{a}$ & $\mathrm{n} / \mathrm{a}$ & $\mathrm{n} / \mathrm{a}$ & $\mathrm{n} / \mathrm{a}$ \\
\hline Prosocial employment ${ }^{c}$ & 16 & 87 & 18.4 & 56.3 & 0.463 & 0.377 & 0.415 \\
\hline
\end{tabular}




\section{SOCIOLOGY OF RELIGION}

and secular giving, which was coded one for respondents who did all three and zero for those who engaged in zero to two of these behaviors. I did this to separate the most prosocial respondents, who engage in helping others in three different domains, from those respondents who engage in only moderate amounts of helping.

There was no survey question on MIDUS that measured prosocial motivation in paid employment, but the interviews explicitly addressed this question, and the coders rated the respondent's level of prosocial motivation at work. They rated each interview on a zero through two scale, with zero meaning that the respondent made no mention of prosocial motives in their paid employment, one meaning some mention, and two meaning frequent or strong mention of prosocial motives in their paid work. The coder agreement was low, with much of the disagreement coming over whether to code respondents as zero or one on this scale. Accordingly, I recoded this variable to a dichotomous measure, with respondents coded as one if they made frequent or strong mention of prosocial motives in paid employment, and zero for respondents who made no mention or only some mention of prosocial motives. Under this scheme, all three coders were in agreement 59.7 percent of the time.

\section{FINDINGS}

\section{Open Coding}

Open coding revealed six themes in how respondents related religion and helping. The section below defines each theme and provides quotes from the interviews that illustrate each theme. After defining these themes, I present quantitative data on intercoder reliability, and the relationship between these themes and prosocial actions.

Religious identity. The MIDUS interviewer guide contained a question about how important the respondents' religious and spiritual beliefs were to their sense of self. The interviewers often neglected to ask this question, so there were valid responses in only 64 cases. Twenty-four out of these respondents (37.5 percent) considered religion very important to their sense of identity, and two examples of these respondents' statements are presented below.

[My religious belief is] integral. And I think it's integral in everyone. Their sense of belief or lack of belief shows up in everything that they are, they do, they think, they say.

I think [my religious belief] has everything to do with me. My compassion for others. It gives me a deeper understanding of charity, heart. It gives me a deeper understanding in His complete love for each and every one of us.

Religious definitions of morality. The MIDUS interviewers asked most of the respondents to define "morality," and 18 of the 86 respondents (20.1 percent) who were asked this question defined morality in religious terms. 
Morality is, the way I was raised was, what God wanted [me] to be, what He expected of me.

Looking at [morality] from a religious or Biblical perspective. I mean, you look at the Ten Commandments. If everybody in society just abided by those Ten Commandments, you wouldn't have a need for jails or anything.

Morals have more to do with an individual's religious upbringing. . . . I think, "What's the right thing to do?", and what guides me in those decisions are traditional Christian teachings.

Equating religiosity with helping. Twenty-four (27.3 percent) of the 88 respondents with valid data made a specific connection between their religious beliefs and helping others.

[My] Habitat for Humanity work and church work are all related to my religious convictions that we're responsible for each other and you ought to help people out who are worse off than you are.

I believe that in living you should not harm yourself and not harm other people, and beyond that do things that are good for yourself and do things that are good for other people, and I think there's kind of a progression there, and I think that religions help you along that way.

God's mission. Eighteen of the 88 respondents (20.7 percent) went beyond general statements about God's will, and stated that God had chosen or created them for a particular mission. Some of these respondents specified that this mission included helping others, but this category was coded positively whether or not they mentioned helping.

I believe that each human being that walks the face of the earth was hand-picked by the Creator, and it's not happenstance that we're here, but each of us have a mission, and that once we've completed that mission, we're no longer needed and we're out of here.

I'm a created person who is created by somebody who had a plan and purpose, and because of that plan and purpose has certain strengths and weaknesses He has built in me that I can pursue those plans and purposes with.

Jesus as inspiration. Seven out of the 79 Christian respondents (8.9 percent) stated that Jesus was their inspiration for helping others, either through his teaching and example, or through his sacrifice on the cross.

I believe that there is a power, a being, or whatever, there is an entity that is greater than Man. And that there is good and evil . . . in all of us. I think that the purpose of religion is to bring out the good and to suppress the evil that's in all of us. That was the gift that Jesus had, his ability to do that, to bring out the good and suppress the evil. And to lead by example, as well as by sermon.

I have a relationship with Christ, a personal, deep relationship. I still read my scripture and learn His words, and I still pray. I make Him the focal point in my life, which means when I get up in the morning, Jesus is in my thoughts, and when I go to bed at night, Jesus is in my thoughts. . . . [This gives me] compassion for others. It gives me a deeper understanding of charity, heart. 
I believe that God sacrificed His son for our sins by the shedding of His blood. I believe that in doing so, He showed, or gave the ultimate sacrifice of love. I also believe that that is something that He would want us to share with our friends and neighbors, and just kind of emulate basically that same love.

During the first wave of qualitative coding, I noticed that there seemed to be a difference between liberal Christians, who talked about Jesus's teaching and example, and born-again Christians, who talked about Christ's sacrifice. I divided the respondents into two groups based on their answers to a yes or no question from the MIDUS survey, "Have you ever been 'born again,' that is, had a turning point in your life when you committed yourself to Jesus Christ?" While some scholars use denominational membership to classify Christians (Steensland et al. 2000), I used the born-again question because the key distinction seemed to be how respondents defined their relationship with Jesus.

The results partially confirmed my initial impression, because all three respondents who spoke about Christ's sacrifice were born-again Christians. However, both born-again Christians (four respondents) and liberal Christians (three respondents) found inspiration in Jesus's teaching and example. In other words, born-again Christians take both Christ's sacrifice and Jesus's teaching and example as inspiration for helping others, but liberal Christians only look to Jesus's teaching and example. The third section of this paper presents extended excerpts from respondents' narratives to demonstrate in more depth how Jesus's teaching and example and how Christ's sacrifice motivate liberal and born-again Christians differently.

Deepening religious faith. The MIDUS interviewers asked respondents if their religious beliefs had remained stable through their lives, or had changed over time. Out of the 83 respondents who were asked this question, 10 (11.4 percent) reported a decrease in religious commitment, 46 (55.4 percent) reported no change, 20 (24.1 percent) reported a gradual increase, and seven (8.4 percent) reported a major change. Below are the statements of two respondents who reported a gradual increase.

I've become more attuned. The basic thing that I felt at thirteen has followed me all the way through. But I certainly have grown in wisdom in my appreciation of all that is involved. Just being involved in Bible study, it's a natural gradation of things that happen to you, an evolution. And it wasn't like a bolt of thunder or anything like that. But certainly it transforms.

You know, all the while I was growing up, religion was more of a routine than anything else. And it wasn't until, I guess, my mother passed away that . . . I couldn't go to church for a long time after that, because the relationship between my mother and church was so strong that it really choked me up. And that's when I had sort of a metamorphosis. I wasn't born again, but I saw religion in a personal way, and my relationship with God became personal.

After I identified these six themes through open coding, I had three independent coders rate each interview for each of the six themes. The initial coding scheme involved a three-point scale for religious identity (not at all important, 
somewhat important, and very important), and a four-point scale for religious change over time (less religious, no change, gradual increase, and major change). However, interrater reliability was low for these two measures, with complete coder agreement on only 28.4 percent of the cases for religious identity and 39.8 percent of the cases for religious change. For religious identity, I collapsed "not at all important" and "somewhat important" into a single category, which improved interrater agreement to 68.8 percent. For religious change, I collapsed less religious and no change into one category, and gradual increase and major change into another, which increased interrater agreement to 65.8 percent. Finally, as there were only four respondents whom the coders thought made a strong connection between religion and helping, I collapsed the strong and moderate connection categories into a single category. Complete statistics on interrater reliability and the percentage of respondents coded positively for each category are presented in table 1 .

Overall, Cohen's $\kappa$ scores for interrater reliability ranged between 0.253 and 0.777. Everitt (1996) states that a rough rule of thumb for evaluating Cohen's $\kappa$ is to consider values between 0.21 and 0.40 "low," between 0.41 and 0.60 "moderate," 0.61 and 0.80 "solid," and 0.81 above "near perfect," while Hoyt (2010) describes Cohen's $\kappa$ values below 0.40 as "poor," $0.40-0.75$ as "fair-to-good," and above 0.75 as "excellent." By these standards, interrater reliability for most variables was only moderate. However, Everitt warns that researchers should not blindly follow these arbitrary standards, but should evaluate reliability in light of the data used and the claims being drawn. As Kurusaki (2000) points out, coding interviews for complex general themes is more difficult than coding individual sentences or phrases for simple elements, so one can expect lower coder agreement. In this case, raters were coding for complex and subtle themes drawn from open-ended interviews, in which interviewers did not always ask questions specifically related to each theme, so the fact that interviewers found only low-to-moderate reliability is not surprising. However, given the limitations in inter-rater reliability, the hypothesis testing below should be viewed as supportive of preliminary conclusions, to be tested more rigorously in future studies.

\section{Hypothesis Testing}

I used Pearson's $\chi^{2}$ to test whether the presence of the religiosity themes had a statistically significant association with volunteering, religious giving, secular giving, participation in all three behaviors, and prosocial paid employment. I tested six hypotheses:

H1. Religious identity: Respondents who described religion as central to their identity are more likely to engage in prosocial behaviors.

H2. Religious morality: Respondents who defined morality in religious terms are more likely to engage in prosocial behaviors. 
H3. Religion and helping: People who explicitly connected their religious beliefs with helping others are more likely to help others.

H4. God's mission: People who felt that God had a specific mission for their life are more likely to engage in prosocial behaviors.

H5. Jesus inspires helping: People who found inspiration for helping in Jesus are more likely to help others.

H6. Religious growth: People who reported an increase in religious commitment through their lives or a major change in their religious beliefs are more likely to help others than those who reported no change or a decrease in commitment.

Tests of these hypotheses revealed positive associations between most of the religiosity themes and prosocial behaviors, some of which reached statistical significance (table 2). Feeling that God has a mission for oneself was not strongly related to helping behaviors, and defining morality in religious terms was significantly related only to religious giving. However, there were statistically significant relationships with two or more helping behaviors for religious identity, religious growth, and being inspired by Jesus's actions and example, and equating religion and helping. The strength of these associations was moderate, as values on Kendall's $\tau$-b, a measure of association for ordinal variables, generally ranged between 0.2 and 0.3 . This moderate correlation is common in studies that compare religiosity and helping (Saroglou 2006).

Religious identity. Respondents who engaged in volunteering, religious giving, secular giving, and prosocial paid employment were more likely to report that their religious beliefs were very important to their sense of identity. This relationship was statistically significant $(P<.05)$ for volunteering (Kendall's $\tau$-b $=0.312$ ) and religious giving $(\tau=0.261)$, and for those respondents who engaged in the combined behaviors of volunteering, religious giving, and secular giving $(\tau=0.223)$.

Religious morality. Respondents who defined morality in religious terms were more likely to engage in prosocial behavior, but this difference was statistically significant $(P<.05)$ only for religious giving $(\tau=0.279)$.

Religion and helping. People who explicitly connected their religious beliefs with helping others were more likely to help others. This was borderline significant $(P<.10)$ for religious giving $(\tau=0.202)$, and significant $(P<.05)$ for volunteering $(\tau=0.248)$, secular giving $(\tau=0.173)$, combined volunteering and giving $(\tau=0.241)$, and prosocial employment $(\tau=0.274)$.

God's mission. There were no statistically significant correlations between believing that God had a mission for one's life and any of the prosocial behavior measures.

Jesus inspires helping. While people engaged in prosocial work in all categories were more likely to state that Jesus inspired their helping behavior, these differences were statistically significant $(P<.05)$ only for combined giving and 
TABLE $2 \chi^{2}$ Tests of Independence and Kendall's $\tau$-b Statistic of Strength of Correlation Between Religiosity and Prosocial Behavior

\begin{tabular}{|c|c|c|c|c|c|c|c|c|c|c|}
\hline & \multicolumn{2}{|c|}{ Volunteering } & \multicolumn{2}{|c|}{ Religious giving } & \multicolumn{2}{|c|}{ Secular giving } & \multicolumn{2}{|c|}{ All three combined } & \multicolumn{2}{|c|}{ Prosocial work } \\
\hline & No Yes & $\begin{array}{l}\text { Kendall's } \\
\tau \text {-b }\end{array}$ & No Yes & $\begin{array}{l}\text { Kendall's } \\
\tau \text {-b }\end{array}$ & No Yes & $\begin{array}{l}\text { Kendall's } \\
\tau \text {-b }\end{array}$ & No Yes & $\begin{array}{l}\text { Kendall's } \\
\tau \text {-b }\end{array}$ & No Yes & $\begin{array}{l}\text { Kendall's } \\
\tau \text {-b }\end{array}$ \\
\hline Religious identity & $26.353 .8^{* *}$ & 0.312 & $25.053 .6^{* *}$ & 0.261 & 28.043 .6 & 0.005 & $29.469 .2 * * *$ & 0.223 & 31.042 .9 & 0.048 \\
\hline Religion $=$ morality & 18.923 .5 & 0.027 & $12.032 .4 * *$ & 0.279 & 21.620 .0 & -0.058 & 18.331 .3 & 0.103 & 22.020 .0 & 0.009 \\
\hline Religion $=$ helping & $18.541 .2 * *$ & 0.248 & $19.637 .8 *$ & 0.202 & $18.434 .0 * *$ & 0.173 & $22.250 .0 * *$ & 0.241 & $14.639 .1 * *$ & 0.274 \\
\hline God has a mission & 18.524 .2 & 0.069 & 16.027 .0 & 0.135 & 21.120 .4 & -0.008 & 19.725 .0 & 0.051 & 19.522 .2 & 0.033 \\
\hline $\begin{array}{l}\text { Jesus inspires } \\
\text { helping }\end{array}$ & 8.316 .1 & 0.120 & 6.518 .2 & 0.181 & 5.915 .6 & 0.151 & $7.728 .6^{* *}$ & 0.251 & $5.317 .5^{*}$ & 0.191 \\
\hline Religious growth & 26.541 .2 & 0.154 & $21.745 .9 * *$ & 0.257 & $20.640 .8^{*}$ & 0.212 & $25.462 .5^{* * *}$ & $=0.313$ & 30.832 .6 & 0.019 \\
\hline
\end{tabular}

Note: Significance tests indicate the significance of the relationship as measured by $\chi^{2}$.

$* P \leq .10 ; * * P \leq .05 ; * * * P \leq .01$. 
volunteering $(\tau=0.251)$, and were borderline significant for prosocial employment $(\tau=0.191)$. The nine non-Christian respondents were excluded from this analysis.

Religious growth. Respondents who had experienced a dramatic change or gradual growth in their religion during their adult lives were more likely to help others. These differences were borderline significant $(P<.10)$ for volunteering $(\tau=0.212)$ and statistically significant $(P<.05)$ for religious giving $(\tau=0.257)$ and for combined volunteering and giving $(\tau=0.313){ }^{1}$

\section{Narrative Data}

The previous section showed that the religiosity themes developed in this paper were particularly effective in predicting participation in multiple forms of helping behavior. The following section focuses on three individuals who participated in all four forms of helping behavior studied in this article: they did volunteer work, gave money to secular charities, gave money to religious charities, and expressed prosocial themes in their paid employment. Extensive quotations from their narratives show how these three highly prosocial individuals relate religion and helping, and how they express multiple religious themes in their interviews. Their narratives also show how liberal and born-again Christians differ in how they connect helping others with Jesus.

Importance of religion. The following three examples show how religion holds central importance in the lives of some of the most prosocial individuals in the sample, and also shows how these respondents invoke multiple religious themes when talking about the connection between religion and helping.

The first respondent, Jo Anne, is an evangelical Christian. She attended church as a child and adult, but dates her current religious faith from a profound experience she had while volunteering at a summer camp with her church's youth group. "I was sitting on a bench with one of the girls, and the minister was praying with the girl to accept Christ as her Lord, and I heard somebody say to me, 'You cannot ask somebody else to do what you've not done yourself.' So audibly that I turned around to see who was there and there wasn't anybody there. And I knew that God knew me, and knew what was going to be coming up in my life, and I had to know who He was, and I had to have that strength and that foundation or I wasn't going to be able to get through."

${ }^{1}$ I used correlations and factor analysis to discover whether the six variables aligned in a meaningful way, but did not find any important patterns. Many of the religiosity variables were correlated with one another, although none of the correlations exceeded $R=0.400$. Principal components analysis showed two factors with eigenvalues greater than 1 , which explained 54.4 percent of the total variance. All of the variables loaded on the first factor at greater than .400 , except for God's mission. This variable loaded on the second factor at 0.827, along with God's mission (0.416) and Jesus's example/Christ's sacrifice $(-0.401)$. This loading pattern did not seem to have any theoretical significance, and rotating the factors did not create meaningful results. 
Jo Anne's prosocial behavior is extensive. She volunteers at her church as a Sunday School teacher, youth group leader, and lay counselor. Jo Anne gives 10 percent of her household income to the church and religious charities, and contributes money to secular charities. Her paid work, cleaning up construction debris from newly built houses, is not intrinsically prosocial, but she views it as work done "under the Lord," and reflects on how happy the people who move into their houses will be with their clean, new homes.

Jo Anne expresses her moral beliefs in religious terms, has become more religious over time, and connects her religious beliefs with helping others. "Morality is being true to yourself," she explains, "and to be true to yourself first you have to be true to God." While she describes her born-again experience as a sudden and striking life change, she also states that her commitment to religion has deepened over time. Before her born-again experience "I knew there was God and I knew there was Jesus, but I knew them intellectually. I was probably saved, but, well, it moved from my head to my heart. Since then, it hasn't changed; it has just grown in knowledge of that fact."

The second respondent, "Arnold," volunteers with his church as a member of the governance board. He does construction work for Habitat for Humanity, donates money to Habitat, and participates in Habitat fund-raising drives. When he worked full time, he tithed 10 percent of his income to charity, and when he retired he continued to donate the same dollar amount as before, even though his income greatly decreased. Some of his donations go to his own church, but much of it goes to church missions that assist the poor.

Arnold described a significant growth in his religious faith in his late adult life, which caused him to greatly increase his volunteering and charitable giving. Through most of his life, Arnold attended church not due to a strong religious faith, but because his wife attended and because he thought a religious education would be good for his children. As a church member and volunteer, Arnold was "never very devoted or dedicated. I became more and more involved from the administrative, volunteer point of view, but not in any way that was really deep inside me."

This all changed about seven years before the interview, when Arnold enrolled in a weekend religious retreat program called "Cursillo."

It was almost a life-changing experience, I would say, not that any great revelation came down or tons of fire descended on our heads, or anything like that, but it crystallized things, and broke a log-jam of puzzlement and indifference, and clarified some things about the Christian faith. The focus of that whole thing is to gradually make you aware of being loved by other people, and how good that feels. And so, you sort of put things together. "Hey! That's what they've been talking about all this time, all these church services I've been going to, and all these sermons I've read and the readings I've heard. "It sort of came together for me then, and from that time on, my spiritual life has been an important part of my life, and up until that point it was a pretty secondary plain-vanilla routine. 
"Barbara," an evangelical Christian, does volunteer work, engages in prosocial behavior through her paid work, and gives extensively to charity. Barbara volunteers at her children's school, and she and her husband served as co-Presidents of the Parent-Teacher fellowship. At church, Barbara plays piano during services, leads the children's choir, teaches Sunday School, and participates in mission trips. Barbara donates money to her church, political advocacy groups, her college, and a number of secular charities.

Religion has been central to Barbara's identity since the third grade, when "I made a public profession of my faith and became a church member." When speaking of her identity, she defines herself as a "created person," "created by somebody who had a plan and purpose." Barbara views morality through "Judeo-Christian ethics, and the Bible is the basis of helping to define it. He's the creator, and this is the basic instruction book of how things work best. He's absolute perfection, but we are not, and He created us with the ability to make choices, good and not good—or wise and unwise."

Barbara describes her nursing career as "not just a job, but a ministry, a significant thing." In working with seriously ill patients, she tries to "help people to realize that God is there in those kinds of circumstances, and He cares. And to help them to find meaning and purpose through it, rather than just devastation."

While Barbara's dates her religious identity from childhood, she feels that her faith has grown and deepened through her adult life. College was a particularly important time for her, as she took theology courses and joined a Bible study group. In the course, "we read Paul Tillich, Dietrich Bonhoeffer, and different theologians and different references of thought. I had become a Christian, and I had grown in my understanding of what that meant, but I was challenged on a different level than I had been challenged before." She also joined the Inter-Varsity Christian Fellowship, which meant "going through the Bible and finding out what it actually says, instead of just what somebody else tells me. And it's a different understanding. It's not somebody telling me what to believe, but it's mine because I've looked in there."

Jesus as inspiration. Barbara, Jo Anne, and Arnold all drew upon Jesus as inspiration for their helping activities, but did so in different ways. Jo Anne, a born-again Christian, was inspired exclusively by Christ's sacrifice, while Arnold, a liberal Christian, was motivated to help others by Jesus's teaching. Barbara, a born-again Christian, drew upon both Jesus's example and Christ's sacrifice, although the latter seems to be a more powerful source of inspiration.

Jo Anne traced her prosocial behavior to her born-again experience, and talked exclusively about the importance of Christ's sacrifice. As a result of her mystical experience at the summer camp, "I realized that God loved me, no matter what I was and no matter what I did, and that made me look at myself in a whole different light. I realized that God was my Father, and that my Brother had gotten on the cross and died for me, no matter if anybody else had needed him, he had died for me. And I had never had anybody who loved me 
that much before, and this was fact. Now that changes you, once you realize that kind of love doesn't come from just anybody, that unconditional love."

Arnold, a liberal Christian, talked exclusively about Jesus's teachings, not about Jesus's sacrifice. Arnold defined his moral code as "the admonitions and exhortations of Jesus to love your friends, and love your neighbors, generalized to mean to be responsible and don't treat other people the way you wouldn't want them to treat you, and treat other people the way you would like them to treat you, with a special bias toward helping those who are most in need."

Barbara, an evangelical Christian, found inspiration both in Jesus's example and in Christ's sacrifice. When human beings went against God's authority, they created evil for themselves, which "has passed on from generation to generation. And yet, He loved us so much that He didn't leave us in this scenario, but $\mathrm{He}$ wanted to let us know that $\mathrm{He}$ cared so much that $\mathrm{He}$ sent a person, his son, in the form of a person, living a life that was giving, and sharing, and yet demonstrating his submission to God and obedience to God. Even willing to die on a cross, if that's what God wanted him to do. Putting his interest aside and following God's interest." Barbara connects Christ's sacrifice with God's mission for her life. "Not only did God personally create me, and have a plan and a purpose for me, but He also had a way of redeeming me, and it's a process" that will continue "until Jesus comes again to reign as King of kings."

\section{DISCUSSION}

This study documents how religious ideas and values, transmitted through language, motivate helping behaviors. While some quantitative studies of religion and helping treat congregations as a type of social network, this study argues that the connection between religious attendance and helping cannot be explained merely in terms of exposure to requests for help, compliance with external norms, and concern for reputation. On the contrary, people learn ideas and values of helping through the language of sermons, texts, and conversations, and internalize them into their own identity. They act on these ideas and values by helping others, and use religious language to construct accounts of their behaviors.

Open coding revealed six themes that describe the connection between religion and helping, and quantitative coding demonstrated a connection between many of these themes and prosocial behavior. While the correlations found between themes and helping behaviors do not by themselves demonstrate causality, in many cases the respondents themselves drew these causal connections in their narratives. Strongest support was found for the theme of explicitly linking religion and helping, followed by considering religion central to one's identity, and religious growth over time. Finding inspiration in Jesus correlated with two prosocial behaviors, equating religion with morality 
correlated only with religious giving, and feeling that God had a specific mission for one's life did not correlate significantly with any helping measure. The reason for this may be found in the resemblance between the theme of God's mission and the theme of divine control. Some people who have a strong sense of divine control feel that God's power and purpose places events outside of their own personal control (Schieman et al. 2005). These people may be less likely to help others, as they may conclude that God will bring about good in the world without the need for them to act.

While quantitative studies have found that subjective religiosity was not as strong a predictor of religious helping as religious attendance, this paper suggests that this finding may be explained by inadequate measures of subjective religiosity. Future surveys could include questions about whether respondents consider helping others to be a central teaching of their religion, whether their religion is central to their identity, and whether their religious commitment has increased or decreased over time. Surveys might also ask Christian respondents how much importance they place on Jesus's role as a teacher, exemplar, and sacrifice.

One of the most interesting findings of this study was that subjective religiosity had the strongest relationship to helping when one considered involvement in multiple prosocial behaviors. People who did volunteer work, gave money to religious charities, and gave money to secular charities were significantly more likely than less prosocial people to have a strong sense of religious identity, equate religion with helping, find inspiration for helping others in Jesus, and experience religious growth or change over the life course. This suggests that the relationship between religiosity and helping may not be strictly linear. For people who do ordinary amounts of volunteering and charitable giving, religion is just one motivation among others, but for highly prosocial people, religion seems to be very important. Perry et al. (2008) and Colby and Damon (1992) came to similar conclusions, but they used selective samples of highly prosocial people only. This study replicates their findings in a nationally representative random sample that includes less prosocial respondents as a comparison group.

While Wuthnow stated that liberal Christians rarely connected their religious beliefs with helping others, the data in this sample only partially supported his conclusion. Born-again Christians were more likely to mention religious motives for helping than liberal Christians, but liberal Christians nonetheless did connect religion and helping. The difference between the two groups seems to be in how they make this connection. While born-again Christians cited both Jesus's teaching and example and Christ's sacrifice as inspiration for helping, liberal Christians only cited Jesus's teaching and example.

This article contains some features that limit its validity and generalizability. While the sample was more closely representative of the U.S. population than most qualitative samples, the large number of nonresponders raises the 
possibility of bias. The measures of the six themes were not perfectly accurate, as many were taken from spontaneous responses during interviews, not responses to direct questions designed to measure those themes. Intercoder agreement was low to moderate for most themes. However, these measurement problems do not invalidate the article's findings. If it was possible to find a correlation between religion and helping even with the rough measures used here, interview and survey questions designed specifically to measure these themes would likely find even stronger results.

Despite these limitations, this article demonstrates the importance of language, values, and ideas in explaining why religion motivates some people to engage in helping behaviors. Sociologists of religion should not discount language as unimportant or nonsociological. On the contrary, language connects the public discourse of religion with individuals' internal values, feelings, and ideas, and helps them explain how these internal states influence their behavior. This study demonstrates why simple measures of subjective religiosity fail to explain helping behaviors, and shows how scholars can use more nuanced questions in surveys. Of particular interest is the finding that religion and spirituality were most important among the most prosocial respondents in the surveyrespondents who have integrated both their religious beliefs and their commitment to helping others into all aspects of their lives. Future studies of religion and helping should continue this focus on how religion not only motivates ordinary volunteering and charitable giving, but also inspires some people to make helping others the central focus of their lives.

\section{ACKNOWLEDGMENTS}

The author would like to thank Rachel Lovell, Paula Dempsey, and the editor and anonymous reviewers of Sociology of Religion for their comments and assistance with this manuscript.

\section{REFERENCES}

Batson, C. Daniel. 1991. The Altruism Question: Toward a Social-Psychological Answer. Hillsdale, NJ: Lawrence Erlbaum Associates.

Becker, Penny Edgell, and Pawan H. Dhingra. 2001. "Religious Involvement and Volunteering: Implications for Civil Society.” Sociology of Religion 62:315-35.

Clary, E. Gil, and Mark Snyder. 1991. "A Functional Analysis of Altruism and Prosocial Behavior: The Case of Volunteerism." Review of Personality and Social Psychology 12:119-48.

Clary, E. Gil, Mark Snyder, Robert D. Ridge, John Copeland, Arthur A. Stukas, Julie HaugenPeter Miene. 1998. "Understanding and Assessing the Motivations of Volunteers: A Functional Approach." Journal of Personality and Social Psychology $74: 1516-30$. 


\section{SOCIOLOGY OF RELIGION}

Cnaan, Ram A., and R. S. Goldberg-Glen. 1991. "Measuring Motivation to Volunteer in Human Services." Journal of Applied Behavioral Sciences 27:269-84.

Cnaan, Ram A., Amy Kasternakis, and Robert J. Wineburg. 1993. "Religious People, Religious Congregations, and Volunteerism in Human Services: Is There a Link?" Nonprofit and Voluntary Sector Quarterly 22:33-51.

Colby, Anne, and William Damon. 1992. Some Do Care: Contemporary Lives of Moral Commitment. New York: Free Press.

Colby, Anne, Lorrie Sippola, and Erin Phelps. 2001. "Social Responsibility and Paid Work in Contemporary American Life. In Caring and Doing for Others: Social Responsibility in the Domains of Work, Family, and Community, edited by Alice Rossi, 463-504. Chicago: University of Chicago Press.

Everitt, Brian S. 1996. Making Sense of Statistics in Psychology: A Second-Level Course. Oxford, UK: Oxford University Press.

Hoge, Dean R. 1995. "Explanations for Current Levels of Religious Giving." New Directions for Philanthropic Fundraising 7:51-70.

Hoge, Dean R., Charles E. Zech, Patrick H. McNamara, and Michael J. Donahue. 1996. Money Matters: Personal Giving in American Churches. Louisville, KY: Westminster John Knox Press.

- 1998. "The Value of Volunteers as Resources for Congregations." Journal for the Scientific Study of Religion 37:470-81.

Hoyt, Walter T. 2010. "Interrater Reliability and Agreement." In The Reviewer's Guide to Quantitative Methods in the Social Sciences, edited by Gregory R. Hancock, and Ralph O. Muller, 141-54. New York: Routledge.

Idler, Ellen L., Marc A. Musick, Christopher G. Ellison, Linda K. George, Neal Krause, Marcia G. Ory, Kenneth I. Pargament, Lynda H. Powell, Lynn G. Underwood, and David R. Williams. 2003. "Measuring Multiple Dimensions of Religion and Spirituality for Health Research: Conceptual Background and Findings from the 1998 General Social Survey." Research on Aging 25:327-65.

Kurusaki, Karen S. 2000. "Intercoder Reliability for Validating Conclusions Drawn from Open-Ended Interview Data." Field Methods 12:179-94.

Lee, Dong Yul, Chul Hee Kang, Jee Yun Lee, and Sung Hee Park. 2005. "Characteristics of Exemplary Altruists." Journal of Humanistic Psychology 45:146-55.

MacLean, A. Michael, Lawrence J. Walker, and M. Kyle Matsuba. 2004. "Transcendence and the Moral Self: Identity Integration, Religion, and Moral Life." Journal for the Scientific Study of Religion, 43:429-37.

Mastain, Lisa. 2007. "A Phenomenological Investigation of Altruism as Experienced by Moral Exemplars." Journal of Phenomenological Psychology 38:62-99.

Musick, Marc A., and John Wilson. 2008. Volunteering: A Social Profile. Indianapolis: Indiana University Press.

Musick, Marc A., John Wilson, and William B. Bynum Jr. 2000. "Race and Formal Volunteering: The Differential Effects of Class and Religion." Social Forces 78:1539-70.

Oliner, Samuel, and Pauline Oliner. 1988. The Altruistic Personality. New York: Free Press.

Omoto, Allen M., Mark Snyder, and Steven C. Martino. 2000. "Volunteerism and the Life Course: Investigating Age-Related Agendas for Volunteer Action." Basic and Applied Social Psychology 22:181-97.

Park, Jerry Z., and Christian Smith. 2000. “To Whom Much Has Been Given . . .' Religious Capital and Community Voluntarism Among Churchgoing Protestants." Journal for the Scientific Study of Religion 39:272-86. 
Perry, James L., Jeffrey L. Brudney, David Coursey, and Laura Littlepage. 2008. "What Drives Morally Committed Citizens? A Study of the Antecedents of Public Service Motivation." Public Administration Review 68:445-58.

Piliavin, Jane Allyn, and Hong-Wen Charng. 1990. "Altruism: A Review of Recent Research." Annual Review of Sociology 16:27-65.

Regnerus, Mark D., Christian Smith, and David Sikkink. 1998. "Who Gives to the Poor?" Journal for the Scientific Study of Religion 37:481-93.

Saroglou, Vassilis. 2006. "Religion's Role in Prosocial Behavior: Myth or Reality?" Psychology of Religion Newsletter 31, no. 2:1-8.

Saroglou, Vassilis, Isabelle Pichon, Laurence Trompette, Marijke Verschueren, and Rebecca Dernelle. 2005. "Prosocial Behavior and Religion: New Evidence Based on Projective Measures and Peer Ratings." Journal for the Scientific Study of Religion 44:323-48.

Schieman, Scott, and Alex Bierman. 2007. "Religious Activities and Changes in the Sense of Divine Control: Dimensions of Social Stratifications as Contingencies." Sociology of Religion 68:361-81.

Schieman, Scott, Tetyana Pudrovska, and Melissa A. Milkie. 2005. "The Sense of Divine Control and the Self-Concept: A Study of Race Differences in Late-Life." Research on Aging 27:165-96.

Steensland, Brian, Jerry Z. Park, Mark D. Regnerus, Lynn D. Robinson, W. Bradford Wilcox and Robert D. Woodberry. 2000. "The Measure of American Religion: Toward Improving the State of the Art." Social Forces 79:291-318.

Toppe, Christopher M., Arthur D. Kirsch, and Jocabel Michel. 2001. Giving and Volunteering in the United States: Findings from a National Survey. Washington, DC: Independent Sector.

Wilson, John. 2000. "Volunteering." Annual Review of Sociology, 26:215-40.

Wuthnow, Robert. 1991. Acts of Compassion: Caring for Others and Helping Ourselves. Princeton: Princeton University Press.

- 2004. Saving America? Faith-Based Services and the Future of Civil Society. Princeton: Princeton University Press.

Yeung, Anne B. 2004. "The Octagon Model of Volunteer Motivation: Results of a Phenomenological Analysis." Voluntas 15:21-46. 